\title{
Brazilian agencies supporting entrepreneurs: creative destruction for the poor?
}

\section{Agências Brasileiras de apoio a empreendedores: destruição criativa para pobres?}

\section{Rene Jose Rodrigues Fernandes ${ }^{\mathrm{a}}$}

${ }^{a} \mathrm{MSc}$ in Business Administration. Fundação Getúlio Vargas (FGV). Centro de Empreendedorismo e Novos Negócios (CENN). rene. fernandes@fgv.br.

\begin{abstract}
The present article performs a critical discourse analysis in the two main Brazilian agencies aimed at supporting entrepreneurship and business activity, namely Sebrae and Banco Nacional de Desenvolvimento Econômico e Social (BNDES). Sebrae is responsible for fostering entrepreneurship from the beginning, by giving training and advice for entrepreneurs and people willing to start a business. BNDES is the national development bank and borrows money to support businesses in the country, with different kinds of financing, like long term debts, venture capital, etc. We believe both agencies are too focused on supporting what we called Schumpeterian - or innovative entrepreneurship - from micro to big companies. Understanding and exposing how they posit entrepreneurship allows us to question this dominant model and help policy makers to better address the beneficiaries from these agencies. By analyzing their websites, we concluded that they do not clearly state that they are aimed at innovative companies, but their discourse also in not clear that they can help entrepreneurs from the start or even help barefoot entrepreneurs. We end by saying that Sebrae and BNDES should be more user friendly in language and websites, helping disadvantaged entrepreneurs to understand that these agencies are also designed for them.
\end{abstract}

Keywords: Sebrae; BNDES; Critical Discourse Analysis; Innovation; Necessity-driven entrepreneurship.

\section{Resumo}

O presente artigo realiza uma análise crítica do discurso nas duas principais agências brasileiras focadas em apoiar o empreendedorismo e a atividade empresarial, nomeadamente o Sebrae e o Banco Nacional de Desenvolvimento Econômico e Social (BNDES). O Sebrae é responsável por fomentar o empreendedorismo desde os estágios iniciais, dando treinamento e aconselhamento para empreendedores que desejam iniciar negócios. O BNDES é o banco nacional de desenvolvimento e empresta dinheiro para apoiar negócios no país, com diferentes formas de financiamento, incluíndo empréstimos de longo prazo, venture capital, etc. Acredita-se que ambas agências sejam muito focadas em apoiar o chamado empreendedorismo Schumpeteriano, ou inovador, seja nas micro ou grandes empresas. Entender e expor como elas posicionam o empreendedorismo nos permite questionar este modelo dominante e ajudar policy makers a melhor endereçarem seus beneficiários. Por meio da análise nos websites destas agências conclui-se que elas não dizem claramente que são voltadas a empresas inovadoras, mas seus discursos também não são claros ao dizer que podem ajudar empreendedores nascentes ou mesmo barefoot entrepreneurs. O texto encerra dizendo que Sebrae e BNDES deveriam ser mais amigáveis em termos de linguagem e websites, ajudando empreendedores desfavorecidos a compreenderem que estas agências também são pensadas para ajudá-los.

Palavras-chave: Sebrae; BNDES; Análise Crítica do Discurso; Inovação; Empreendedorismo por necessidade. 


\section{Introduction}

Some authors believe that entrepreneurship is a primary catalyst for economic growth and regional development (Minniti, 1999; Zacharakis et al., 2000; Henderson, 2002; Andreassi et al., 2013; De Almeida et al., 2017). Empirical evidence shows that there is a positive relationship between the rate of Total Early-Stage Entrepreneurial Activity (TEA) and the growth of countries' Gross Domestic Product (GDP) (Hall \& Sobel, 2006). The higher the TEA, which measures the percentage of people involved in businesses with up to three and a half years, the greater the GDP growth.

Public policies to foster entrepreneurial activity, however, have not yet proven to be effective in job creation and economic development (Minniti, 2008; Shane, 2009; Acs et al., 2016; Åstebro, 2017). Shane (2009) says that "Policy makers believe a dangerous myth. They think that start-up companies are a magic bullet that will transform depressed economic regions, generate innovation, create jobs, and conduct all sorts of other economic wizardry" (p.141), arguing that policies that seek to increase quantity, to the detriment of the quality of enterprises have been misguided. Minniti (2008) states that the results of public policies aimed at fostering the entrepreneurial activity have been controversial and, with some exceptions, the issue has not been satisfactorily addressed. The literature shows that the question of how, and if, governments can positively influence the rate of entrepreneurship has not yet been resolved (Minniti, 2008).

Brazil has been building public policies over the "romantic and optimistic notions of entrepreneurship as an instrument of social change and sustainable development" (University of Leicester, 2015). For more than 40 years, Brazil has had two main agencies working to foster the development of entrepreneurial companies. One of them, Sebrae (Serviço Brasileiro de Apoio às Micro e Pequenas Empresas), is aimed at helping what we would call lifestyle entrepreneurs. Sebrae "promotes the competitiveness and sustainable development of micro and small enterprises - those with annual gross sales of up to R $\$ 4.8$ million” (Sebrae, 2018). The other, the Brazilian Economic and Social Development Bank (BNDES), is aimed at glamour entrepreneurs, majorly focusing on gazelle or big companies. BNDES is one of the largest development banks in the world and the main instrument for long-term financing and investment in all segments of the Brazilian economy (Bndes, 2017b). Sebrae does not borrow money to its beneficiaries, whereas BNDES does so.

Nowadays, both Sebrae and BNDES seem to be promoting the Schumpeterian entrepreneurship - or the success neoliberal model -, while some publics would be better assisted if they could receive more basic day to day training. This study develops a critical discourse analysis (CDA) focused on these two Brazilian national agencies with the purpose of understanding how and if they are permeable to non-innovative or even barefoot entrepreneurs. Sebrae and BNDES were chosen because they are the most well know organizations in the entrepreneurial ecosystem in two different areas, training and credit, and both are available throughout the country.

While the majority of the research in the field of entrepreneurship policies are in the functionalist paradigm (Burrell \& Morgan, 1979), the critical perspective is useful to question the barriers that the innovation discourse poses to small or disadvantaged entrepreneurs. To this end, CDA is adequate according to van Dijk (2001): CDA "is a type of discourse analytical research that primarily studies the way social power abuse, dominance, and inequality are enacted, reproduced, and resisted by text and talk in the social and political context" (p. 352).

Texts, whether written or spoken, are the major source of reference for CDA because they are constructed in order to communicate particular meanings to the reader or receiver, "revealing values, beliefs, 
and assumptions" (Perren \& Jennings, 2005, p. 175). These agencies websites and the most relevant headlines about them will be, respectively, the primary and secondary sources of evidence due to some advantages. First, the Internet has become the primary communication channel between government and citizens and the agencies websites represent the official discourse. Second, they are broadly accessible for the purposes of this research. Third, that's where it's possible to find the most up-to-date information (Perren \& Jennings, 2005).

Brazil is facing an economic crisis over recent years - unemployment is growing and necessity-driven entrepreneurship is rising again, according to the Global Entrepreneurship Monitor (GEM) 2015 (Macedo et al., 2016). Namely Sebrae, for instance, could be more focused on educating barefoot entrepreneurs - those have-nots who struggle every day to make their living (Imas et al., 2012) - and real lifestyle entrepreneurs, instead of being focused on the same grandiloquent entrepreneurial model as BNDES, that doesn't even give enough return in taxes to the state (Mazzucato, 2013). We believe that understanding and exposing how both agencies posit entrepreneurship will allow us to question this dominant model and help policy makers to better address their beneficiaries from these agencies, differentiating them, and answering the question on how to achieve not just development, but inclusive development.

This paper will be organized as follows. In section two, a review on relevant literature will be performed. In section three it's presented the methodological approach and the sources of information for analysis. Section four presents the results. Finally, the results are discussed in section five and conclusions and implications for policy makers are in section six.

\section{Literature review and research question}

\subsection{Policies on entrepreneurship}

Santos (2013), discussing the reduction of socioeconomic inequalities, shows the role local governments have on development, emphasizing that, since the 1980s, these governments have become concerned about policies to promote job creation, entrepreneurship and support for small and medium enterprises (SMEs). First, there were initiatives to deal with the increase in structural unemployment. This was followed by initiatives to develop new companies, which sought to "value the social role of small enterprises, recognizing them as important for creating jobs and income and for a more territorially balanced economic growth" (Santos, 2013, p. 77). According to Henrekson and Stenkula (2010), this impetus came after David Birch's influential 1979 study, documenting the important role new and small businesses played in job creation and innovation activity. Right after Birch's study, wealthy nations started to develop policies aimed at small and new firms, in the belief that they needed "protection and support relative to large firms due to size-inherent cost disadvantages" (Henrekson \& Stenkula, 2010, p. 595).

For Henrekson and Stenkula (2010), at first there was a focus on levelling SMEs and incentivizing people to become self-employed, which later evolved into a view that the firms that created most jobs were high-impact companies (high-impact entrepreneurship), or gazelle companies, as mentioned before. The new policies were initiated asking "what bundle of policies ensures that people can start new ventures, develop these ventures into high-impact firms, and expand existing ventures to their full potential?" (Henrekson \& Stenkula, 2010, p. 596).

Henrekson and Stenkula (2010) distinguish between entrepreneurship policy and SME policy (Fig. 1). These authors understand, in first place, that self-employment (or owning an SME) is different from 
entrepreneurship. While self-employment can be a way out of problems such as lack of jobs in the traditional job market, they understand that this is not entrepreneurship. Entrepreneurship has a motivational bias, which is pursued by individuals in organizations of any size and time of existence. Entrepreneurship is linked to opportunity and innovation in a broader context. SME policy is focused on encouraging many people to become self-employed or leveraging the playing field to companies that supposedly would have disadvantages in relation to big firms (Henrekson \& Stenkula, 2010). On the other hand, entrepreneurship policy aims to encourage few individuals to become entrepreneurs who will cause bigger social e economic impact. In this way, entrepreneurship policies are necessarily different from policies aimed at SMEs.
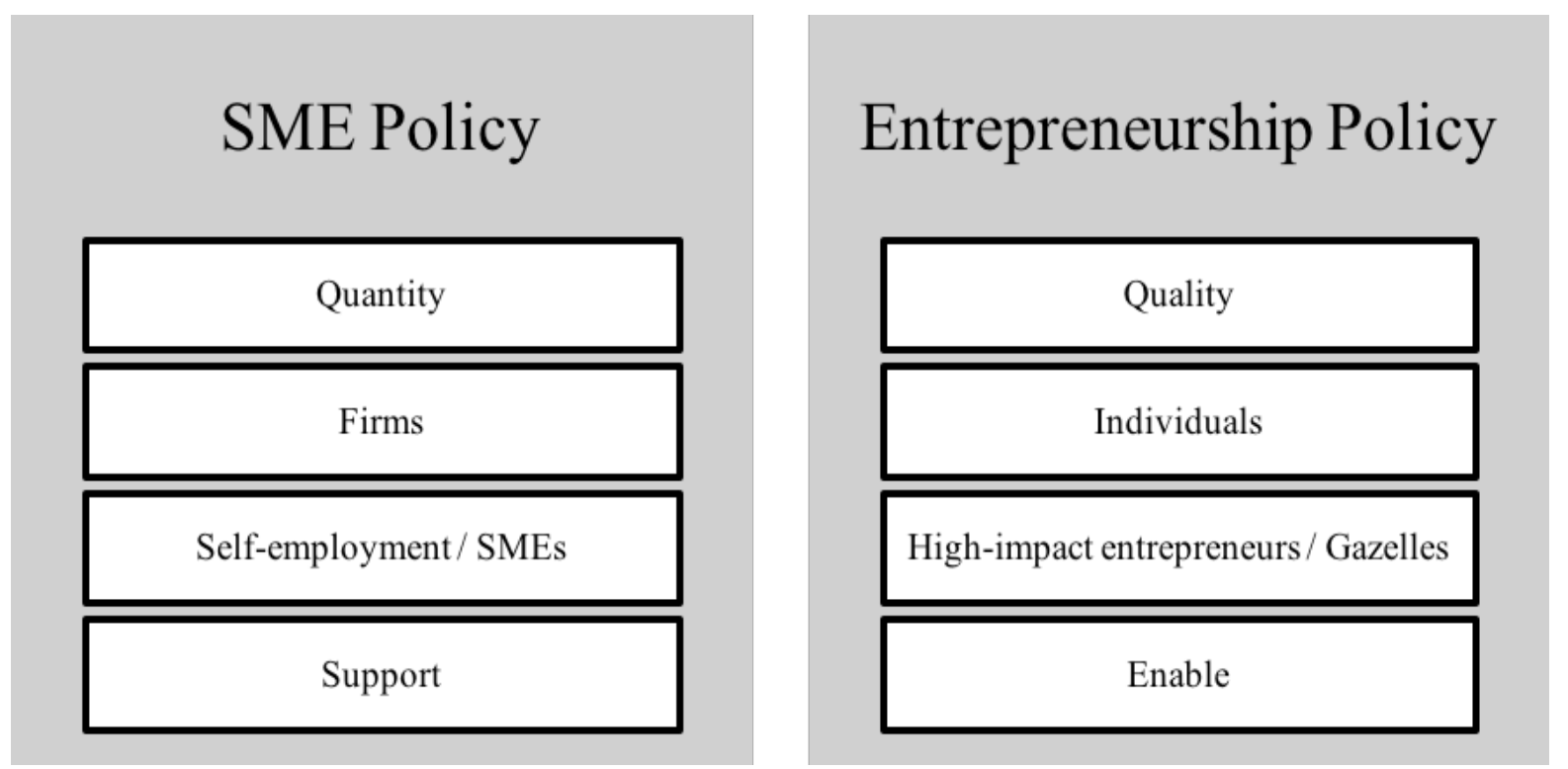

Fig. 1. SME policy versus entrepreneurship policy. Source: Henrekson and Stenkula (2010, p. 600).

Henrekson and Stenkula (2010) suggest that governments should not focus on a large number of SMEs or self-employed people: "[E]mpirical evidence suggests that an economy that fosters (a few) high-impact entrepreneurial firms and high-growth firms is superior to an economy that tries to maximize the number of SMEs or the rate of self-employment" (p. 600).

SME and entrepreneurship policies can take several forms. Gomes et al. (2013) named some of these policies implemented in Brazil by local governments: entrepreneurial education; banks aimed at microcredit; local development agencies; technology parks; incubators and accelerators; programs to reduce red tape; formation of clusters; funding for venture capital; among other initiatives. In the national level, the program Startup Brasil and the individual micro-entrepreneur regulation (MEI) are the most famous policies. The first, aimed at high-impact technology start-ups, on the individual level, with few beneficiaries, and the later, designed to reduce red tape and taxation for microentrepreneurs or self-employed individuals. All these policies, however, lack impact measurement, according to Borges Junior et al. (2017). The contribution of entrepreneurship to economic growth or to poverty reduction in Brazil, according to these authors, is not yet available.

\subsection{From Creative Destruction to Barefoot Entrepreneurs}

Almost one century ago, Joseph Schumpeter put the entrepreneurial activity and innovation as central 
for economic development in his classic book Theory of Economic Development. For Schumpeter (2008), the economic life lives in a circular flow, in which the production of goods and services is static while people's needs are being satisfied. Even if disturbances may occur, like population growth, the tendency is that the economy will always search for its already known equilibrium (Schumpeter, 2008). The author compares the economic life to the blood flow in an animal, which goes through the same veins year after year. Following his logic, economic development only happens with "spontaneous and discontinuous change in the channels of the flow, disturbance of equilibrium, which forever alters and displaces the equilibrium state previously existing" (Schumpeter, 2008, p. 64). This change is not conditioned by changes in customer preferences, but essentially in the sphere of the industrial and commercial life with the realization of new combinations - in other words - innovations. And innovation, for Schumpeter, is:

(1) The introduction of a new good [...]. (2) The introduction of an improved or better method of production, [...] (3) The opening of a new market [...]. (4) The conquest of a new source of supply of raw materials or half-manufactured goods, [...]. (5) The carrying out of the better organization of any industry [...] (Schumpeter, 2008, p. 66).

Who is responsible for the process of innovation is the entrepreneur. The entrepreneur is the one who puts together the new combinations with credit made available by capitalists - realizing the innovations and starting new business. Not surprisingly, for Schumpeter (2008), the entrepreneurial activity is the "fundamental phenomenon of economic development" (p. 74). The introduction of new combinations in the market will generate profits to the entrepreneur. This profit will feed more innovations, creating economic growth: "Without development there is no profit, without profit no development" (p. 154).

Relevant to say for this work, is the way Schumpeter (2008) sees the entrepreneur: for him, "there is the dream and the will to found a private dynasty" (p. 93), "the will to conquer: the impulse to fight, to prove oneself superior to others, to succeed for the sake, not of the fruits of success, but of success itself" (p. 93), having the financial result as secondary, and finally "the joy of creating, of getting things done" (p. 93). "Schumpeter saw entrepreneurs as heroic figures uniquely possessing the will to introduce revolutionary "new combinations"' (Chiles et al., 2007, p. 470). Apart from saying that financial result is secondary, Schumpeter posits the entrepreneurial profit as the source of most fortunes (Schumpeter, 2008).

Later in his work, in Capitalism, Socialism and Democracy, Schumpeter (1975) focuses on the innovations generated in big companies. That's what Schumpeter called the process of creative destruction, in which the "fundamental impulse that sets and keeps the capitalist engine in motion comes from the new consumers' goods, the new methods of production or transportation, the new markets, the new forms of industrial organization that capitalist enterprise creates" (Schumpeter, 1975, p. 83). Once again, Schumpeter (1975) sees the revolution being created from within, destroying the old one and incessantly creating the new one. Competition is responsible for making firms innovate. With innovation, firms can outperform competitors.

What we fundamentally see in Schumpeter $(2008,1975)$ is that entrepreneurship is not the same as business ownership or, to go further, is not the same as people who, by opportunity, chance or necessity, take control over their lives and become self-employed. Despite the recognition that entrepreneurship can be much more than starting a new innovative business, the Schumpeterian view "is the most influential in the discourse" (Ogbor, 2000, p. 615). And that is not just for Schumpeter: for Drucker (1985) and many other authors, "innovation is the specific instrument of entrepreneurship" (Drucker, 1985, p. 27). According to 
Timmons and Spinelli (2004) an entrepreneurial leader injects imagination, motivation, commitment, passion, tenacity, integrity, teamwork and vision into those at his side. And that's the kind of individual the Brazilian sees on soap operas: the white middle aged male business owner who started a company and became rich. But that is not the reality of the majority. For instance, the country has a legal category of entrepreneurs called individual micro-entrepreneur (microempreendedor individual - MEI), a policy designed for increasing formalization, reducing red-tape and facilitating taxation. The MEI is someone who is self-employed and gets tax benefits for being incorporated as a company. The maximum income for the MEI is R $\$ 81 \mathrm{~K}$ a year and the entrepreneur cannot be partner in other companies. It also allows the entrepreneur to hire up to one employee. Nowadays there are more than 6.8 million MEI in Brazil, according to Portal do Empreendedor - MEI (2018).

According to the GEM, in 2015, 4 out 10 Brazilians (39.3\%) from 18 to 64 years old were involved in starting or running a business, which accounts for approximately 52 million people in the country. Out of them, $46.7 \%$ were female entrepreneurs, $58.1 \%$ had their total family income up to 3 minimum wages (about \$220 USD per month), 94\% didn’t have tertiary education, with astonishing 30.6\% having almost no formal education at all. Only 38.2\% were white (Empreendedorismo no Brasil: 2015, 2016). When they were asked if they looked for any supporting organization, $85.9 \%$ said no. The vast majority of entrepreneurs were informal: $21 \%$ declared to have "some kind of registration", while only $17 \%$ said they had CNPJ, which is the company registration number in Brazil.

GEM also analyses the extent entrepreneurs are introducing products or services that are new to some or all customers, and that are offered by few or no competitors. Out of the entrepreneurs who do not have CNPJ, $89.6 \%$ declared that their product or service is not new to anyone and $7 \%$ declared that it is new to some people. Only $2.7 \%$ declared that no businesses offer the same product while $77.2 \%$ declared that there many other businesses offering the same products or services to their potential customers (Empreendedorismo no Brasil: 2015, 2016). There are many people who are not innovative in the Schumpeterian sense: his analysis excludes someone who starts a non-innovative new business, who inherits a company from family, independent contractors, self-employed individuals, franchisees and many other kinds of people who are out there making their everyday living not being employed in the formal labor market.

Filion (1999) distinguishes between voluntary and involuntary entrepreneurs. Involuntary entrepreneurs are those who were laid off in the early 1990's after corporate closures and downsizing in big companies or new graduates unable to find a proper job and thrown out to have their own business. They are considered to be not innovative nor will constitute the group of people starting gazelle companies, like voluntary entrepreneurs, but will be self-employed and have a balanced lifestyle.

Filion (1999) is talking about a group of people who account for $43.5 \%$ in the TEA, measured by the GEM in Brazil (Empreendedorismo no Brasil: 2015, 2016). Even though, when explaining the meaning of involuntary entrepreneurs, or necessity-driven entrepreneurs, as GEM calls them, Filion (1999) forgets about the giant number of have-nots outside the industrial world who never had a chance to graduate or even to be fired in corporate closures or restructuring. To include them on critical entrepreneurship studies, Imas et al. (2012) present the idea of barefoot entrepreneurs, constructing a parallel to Max-Neef's barefoot economics concept. Max-Neef refers to the work experiences and practices of individuals living in rural or urban communities, that are marginal or peripheral to the dominant neoliberal economic system. "Those areas of exclusion are where the poor have to 'carve out' a way of living in order to survive" (Imas et al., 2012, p. 565). Through the methodology based on the authoring and sharing of microstorias, the authors show that there are people who flee from the neoliberal hegemonic entrepreneurial model of the white man who is able to 
progress and succeed economically with creative destruction or being innovative in business. In these stories that take place in favelas, degraded areas, etc., they encounter a variety of meanings, values, and relationships that challenge the entrepreneurship dominant view. With different forms of public action, often outside the state domain, they can find solutions for their livelihood. One implication for the authors is that governments could give up the well-known financing mechanisms for entrepreneurs and facilitate, for example, microcredit. These people, however, would need to play a more central role in organizing and managing this type of initiative in order for them to work.

From mom-and-pop shops owners, individual entrepreneurs, to barefoot entrepreneurs, this article aims to understand better how and if they fit in the discourse proclaimed by the most important agencies in Brazil aimed at fostering business activity.

\section{Methodological approach and data sources}

It is important to emphasize that this article means to be critical - this presupposes that the reality is socially constructed, and the researcher lives in the same constructed reality under analysis (Burrell \& Morgan, 1979; Furlong \& Marsh, 2010). Being critical means challenging conventional wisdom and the status quo. Opposed to conventional wisdom, for instance, Nyström (2008) shows that, although most of the empirical evidence indicates a positive relation between entrepreneurial activity and economic growth, there are studies in which this relationship is not clear, especially when considering necessity-driven entrepreneurship vs. opportunitydriven and self-employment vs. innovative (Schumpeterian in our sense here) entrepreneurship. Tedmanson et al. (2012) say that "[E]ntrepreneurship as a field of study has generally been dominated by research and researchers interested in it as a purely market-based phenomenon: a 'special' trait or set of behaviours which drive venture creation" (p. 532), not focusing important questions like "identity, phenomenology, ideology and relations of power" (p. 532). The same authors alert us that entrepreneurship can function as a "political ideology which can be used to reproduce conservative assumptions and behaviour and confuse, distort and shape public policy and public perception in ways that serve conservative political or economic (capitalist) ends" (Tedmanson et al., 2012, p. 536). Against this background, a critical analysis will allow to question how Sebrae and BNDES discourses influence the agencies acceptance to their publics.

According to Fairclough (2001), discourses not only reflect or represent entities and social relations, but they build and make part of them. In other words, discourses will shape social relations. For Iñiguez and Antaki (1994), discourse analysis consists in "studying how discursive praxis act in the present, maintaining and promote these relations: it will shed light to the power of language as constitutive and regulating praxis" (p. 63).

Even though there are several types of discourse analysis, the present work will be performed using Critical Discourse Analysis (CDA). CDA is suitable because it allows to question the effects of discourse in social identities, social relations, knowledge systems and beliefs, none of which are usually perceptive to all the participants in a discourse (Fairclough, 2001). According to van Dijk (2001), critical research will also allow to focus on social problems and political issues, understanding their contexts, will allow to have a multidisciplinary view, will explain structures, rather than just describing them and more specifically will allow to understand how discourse relate to power in society. That is emphasized by Fairclough (2010): CDA is relational, which means that its focus is on social relations, not on individuals or organizations; CDA is dialectical, which means that interactions considers the many parties involved and; CDA is transdisciplinary, 
allowing multiple views over the discourse. Finally, is important to note that, for Fairclough (2010) "CDA is not just descriptive, it is also normative" (p. 11). It means that researchers are allowed to address social wrongs on their discourse analysis and find ways to mitigate them.

Regarding the agencies selection, it is possible to find different types of organizations aimed at fostering entrepreneurship in Brazil, from public and private sectors, and NGOs like Endeavor, Junior Achievement, Ashoka, Choice, among others. Sebrae and BNDES, however, became the focus of the present study because they are the most well know organizations in the entrepreneurial ecosystem in two different areas: the former is responsible for training and giving consultancy for entrepreneurs and the latter is the Brazilian development bank, responsible for lending money. Sebrae and BNDES are available throughout the country. Sebrae has divisions for each Brazilian state and agents in hundreds of cities and some of its services can be accessed online (Sebrae, 2018). The services provided by BNDES are available directly with the bank or through commercial banks nationwide (Bndes, 2018). Other organizations have a narrower focus on specific sectors and types of companies (e.g.: the NGO Endeavor clearly states that it's focus is on gazelle companies) or are geographically limited in certain areas, like each state development bank or agency, where they are available.

The main sources of data were both agencies websites. Secondarily headlines published in the Brazilian media in year the of 2017 using Google News (see Mautner (2005) for an initial discussion on web-based corpora in CDA and Perren and Jennings (2005) for a discussion on using websites as sources for CDA) also constituted an important source of information, as they can show more updated information about future steps of these organizations. Using these sources of data two conditions are met: representativeness and effective discursive speech (Iñiguez \& Antaki, 1994). The information available online covers the way both agencies communicate to their publics.

To perform the analysis on the websites, the first step was to find everything related to entrepreneurship and micro, small and medium enterprises, searching for values, beliefs and assumptions that could be embedded in the texts (Perren \& Jennings, 2005). Special attention was given to find support for the MEI. After this general look on the websites, the second step was to visit both as an entrepreneur looking for support and/or credit. On Google News, the procedure was to use the agencies names and (represented by the Boolean operator + ) empreendedorismo (Portuguese for entrepreneurship). As this work is not looking for trustworthiness of the publisher (or quality of the sources) for the headlines, what would sound functionalist, the decision was not to reveal their sources (for an initial discussion on how Google News works see Independent (2018)). The headlines were just translated into English in the ordering presented by Google News and put for analysis, as any person using the search engine would do. The most relevant outcomes were then outlined in the following section.

\section{Results}

This section is aimed at analyzing the language present at both BNDES and Sebrae websites, including mission statements and other relevant information.

When we reach BNDES website (Fig. 2), the first image we see is labelled on the meta tags as "man in the foreground smiles in front of the café counter, where other people are consuming the products of the store" (Bndes, 2017a). The text over the image calls for "micro, small and medium companies" (Bndes, 2017a) to look at the solutions BNDES offers for companies up to R 300 million in revenues annually. While the picture shows a black person in the foreground, we don't know if he is the entrepreneur or not. What we 
see is that he is serving in the café, because of his clothes. The second point that draws attention is the annual revenue up to R $\$ 300$ million. That's far from being the reality of micro or small entrepreneurs. That could be a barrier even to click and look at the solutions.

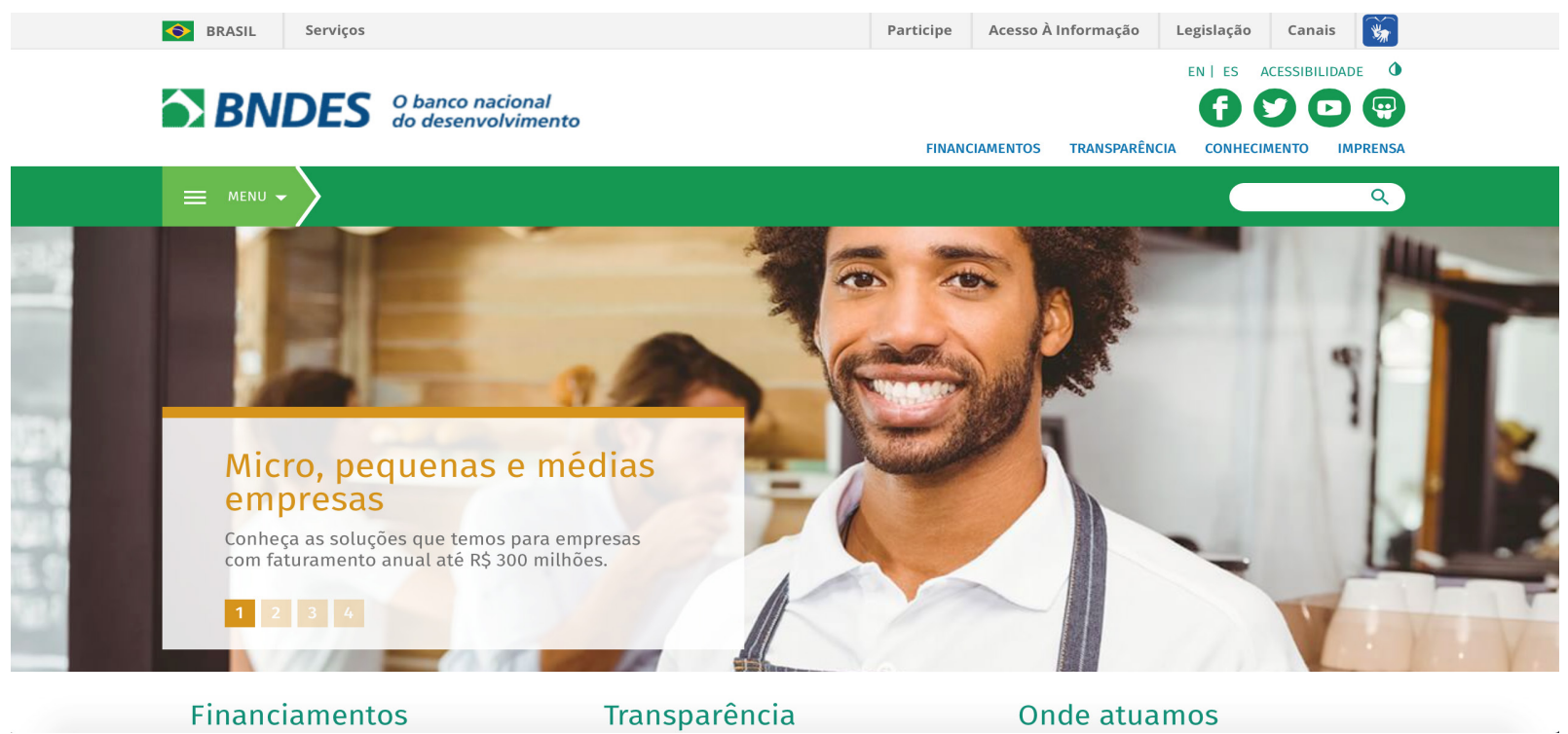

Fig. 2. BNDES website screenshot. Source: BNDES (2017a).

The most remarkable to notice, however, is the tagline besides the name BNDES. While BNDES stands for Brazilian Economic and Social Development Bank (in Portuguese: Banco Nacional de Desenvolvimento Econômico e Social), it only says “The national development bank" (Bndes, 2017a). The bank was stablished in the 1950's, called Brazilian Economic Development Bank - BNDE. At that time, the bank was "a government agency, with the aim of developing and carrying out national economic development policies" (Bndes, 2017b). In the 1970's it became a state-owned company under private law, giving more flexibility. Reflecting the "social concerns with the development policy in the beginning of the 1980s" (Bndes, 2017b) the bank "changed its name to The Brazilian Economic and Social Development Bank - BNDES, in 1982" (Bndes, 2017b). While the bank mission is "[T]o foster sustainable and competitive development in the Brazilian economy, generating employment while reducing social and regional inequalities" (Bndes, 2017b), the mentions to social development have almost disappeared in the website. It only appears in a section linking to social and environmental responsibility programs.

When we click on the link for support for micro, small and medium companies, a warn says that it only provides credit to formalized companies (with CNPJ). That already excludes millions of entrepreneurs. If we dig deeper, in "microcredit" (Bndes, 2017a), however, the bank says that they provide money for formal and informal entrepreneurs, through agents (usually state development agencies or local microcredit banks). BNDES doesn't provide any further information on how to access that credit. It only shows a list of partners. Looking at other options in the same category, it's not easy to understand the steps to obtain support from the bank. It always sends you to partner institutions, like commercial banks.

A search on Google for 10 most relevant news in the period between January 1st 2017 and December 31st 2017 for the keywords BNDES+empreendedorismo (Portuguese for entrepreneurship) shows the headlines on Figure 3. 


\begin{tabular}{|l|l|l|}
\hline Rank & Date & Headline \\
\hline 1 & $2017 / 07 / 18$ & Banks block BNDES loans to small business \\
\hline 2 & $2017 / 11 / 14$ & BNDES creates fund to invest in Brazilian start-ups \\
\hline 3 & $2017 / 01 / 18$ & Government announces R\$ 8.2 billion in credit for small and micro enterprises \\
\hline 4 & $2017 / 11 / 14$ & BNDES announces a R\$ 40 million fund for incubators and technology parks \\
\hline 5 & $2017 / 06 / 20$ & Policy of national champions is “almost a grimace”, says BNDES president \\
\hline 6 & $2017 / 07 / 08$ & Rabello de Castro takes a different course than his predecessor at BNDES \\
\hline 7 & $2017 / 11 / 18$ & In Salvador, PSC launches BNDES president as presidential candidate for 2018 \\
\hline 8 & $2017 / 08 / 23$ & New BNDES line of credit will give “injection of vitality" in companies, says Temer \\
\hline 9 & $2017 / 05 / 26$ & Maria Silvia Bastos leaves BNDES presidency \\
\hline 10 & $2017 / 08 / 24$ & Câmara approves new interest policy for BNDES \\
\hline
\end{tabular}

Fig. 3. Most relevant news according to Google search engine in 2017 for BNDES+empreendedorismo.

The first article in relevance, Banks block BNDES loans to small business (Época Negócios, 2017), according to Google search engine, show that disbursements of Cartão BNDES (BNDES Card), a line of credit for micro, small and medium businesses, fell 60\% between January and May, 2017. Commercial banks, responsible for distributing the money, hardened conditions for lenders on the grounds that they cannot afford the high risk of operations. "Companies complain that bank managers 'hide' the BNDES Card from customers to sell more expensive products" (Época Negócios, 2017), says the text. Although BNDES provides the funds for this type of financing, it does not bear the losses in case of default. The other relevant news were saying about the launch of a new fund aimed at technology based start-up companies and the commitment of the bank to increase its share of funds available to micro, small and medium companies in partnership with the state-owned commercial bank Banco do Brasil and Sebrae. BNDES is also announcing funds for incubators and technology parks. The other news are about changes in BNDES presidency, national politics and policies of the bank.

When analyzing Sebrae website (Fig. 4), the first information we see is about their distance learning courses, with a picture of a laptop in the background. The second screen shows the options they have for customized solutions for micro entrepreneurs, with a picture of a white woman in bakery looking at her laptop and a white man in a space that looks like workshop cleaning a brush and third screen shows the advertisement of their conference on innovation for the industrial sector, with no image on the background, just the logo of the conference. 


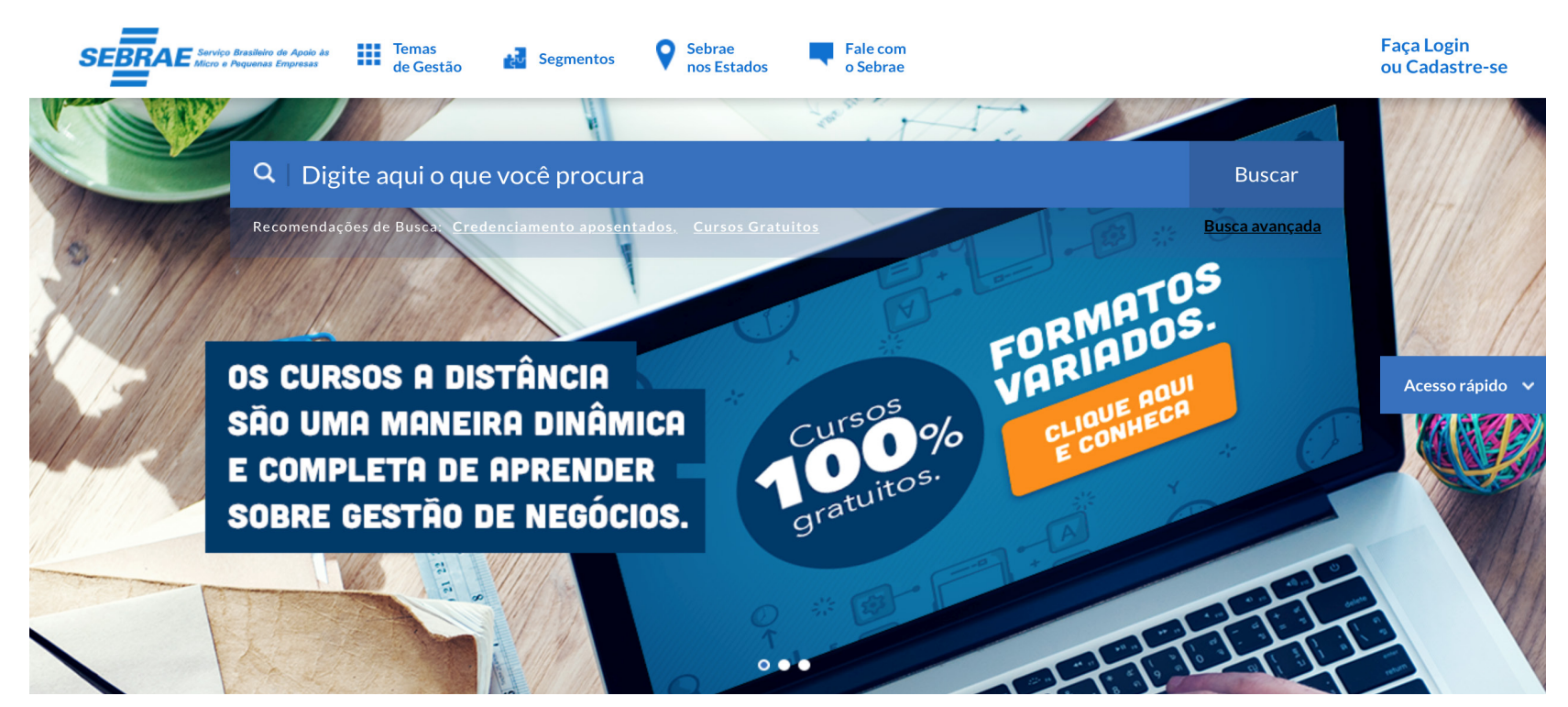

Fig. 4. Sebrae website screenshot. Source: Sebrae (2017).

Scrolling down the webpage we can find information about the services Sebrae provides related to entrepreneurship, planning, finance, market and sales, innovation, cooperatives, human resources, administrative procedures, and regulations. Only in the bottom Sebrae offers service to entrepreneurs who want to become a MEI (Sebrae, 2017). At the "who we are" (Sebrae, 2018) section, Sebrae says its mission is to "promote the competitiveness and sustainable development of small businesses and foster entrepreneurship, [in order] to strengthen the national economy" (Sebrae, 2018).

The two most recent news on the website by the time it was visited were related to innovation: Sebrae participating in the biggest innovation event in the world and small business will more important for innovation in future. The third most recent article was about the process being conducted in Sao Paulo to reduce the time to open a company in the city. Sebrae claims to be working with the municipal authority to reduce the total amount of time for five days. Their final target is to have all the process digital. Now-a-days, entrepreneurs still need to go personally to register in one of the local departments (Sebrae, 2017).

A search on Google for 10 most relevant news in the period between January 1st 2017 and December 31st 2017 for the keywords Sebrae+empreendedorismo shows the headlines on Figure 5.

\begin{tabular}{|l|l|l|}
\hline Rank & Date & Headline \\
\hline 1 & $2017 / 03 / 07$ & Women entrepreneurship grows 34\% in 14 years \\
\hline 2 & $2017 / 05 / 08$ & Microentrepreneurs in the country exceed 7 million, says Sebrae \\
\hline 3 & $2017 / 10 / 02$ & Sebrae-SP promotes activities in Entrepreneur Week \\
\hline 4 & $2017 / 04 / 05$ & Sebrae: entrepreneurs don't think about retirement \\
\hline 5 & $2017 / 11 / 16$ & Government measures facilitates opening news business and stimulate entrepreneurship \\
\hline 6 & $2017 / 02 / 21$ & 10 machines to open a home-based business from 630 Reais \\
\hline 7 & $2017 / 09 / 02$ & Sebrae research reveals profile of potential Entrepreneurs from Joinville \\
\hline 8 & $2017 / 01 / 18$ & Government announces R\$ 8.2 billion in credit for small and micro enterprises \\
\hline 9 & $2017 / 05 / 01$ & Sebrae promotes training for small entrepreneurs in Pernambuco \\
\hline 10 & $2017 / 10 / 05$ & Feira do Empreendedor (Entrepreneur Trade Show) 2017 starts this Thursday in Patos, Paraíba \\
\hline
\end{tabular}

Fig. 5. Most relevant news according to Google search engine in 2017 for Sebrae+empreendedorismo. 
The news found range from data and research about entrepreneurship to actions that Sebrae is promoting to foster entrepreneurial activity, like its trade shows and entrepreneurship week. Some news reveals business opportunities and some focus on training sessions and reducing red-tape. One of the articles, \#8 in rank, had appeared before in the search for BNDES+empreendedorismo, since the release of R 8.2 billion in credit micro and small companies is a joint effort that will involve Sebrae, BNDES and Banco do Brasil. Around R\$ 7 billion will come from BNDES, in a modality in which small and micro enterprises can pay back in up to 60 months, with a grace period of up to 12 months and interest starting at $1.63 \%$ per month. The remaining R $\$$ 1.2 billion will come from a line of credit from Banco do Brasil.

\section{Discussion}

The previous session shows how BNDES and Sebrae introduce them and their services online and present the most relevant results on Google for the ten most relevant news about the two agencies.

Regarding the kind of policy Sebrae and BNDES are making, whether a SME or an entrepreneurship policy (Henrekson \& Stenkula, 2010), they have aspects of both. Sebrae is focused on quantity support for SMEs and self-employed individuals, but much of its content is about innovation. BNDES, while focusing more on big companies, has funds aimed at high-impact entrepreneurs, but also covers SMEs with products such as Cartão BNDES and supports microcredit.

Beyond that, the first important point to note is that both BNDES and Sebrae have the word development in their mission statements. They use development in different senses, however. For BNDES what they do will help on the "[...] sustainable and competitive development in the Brazilian economy [...]" (Bndes, 2017b), while for Sebrae, promoting the competitiveness and sustainable development of small businesses will strengthen the Brazilian economy. Although development for Schumpeter (2008) is a direct fruit of the entrepreneurial activity, studies are controversial about this role. According to Nyström (2008), there is no definitive evidence that entrepreneurship promotes economic development.

Sebrae is not clearly using the word development in the Shumpeterian sense. Sebrae is just focused on development of SMEs. Whatever development may mean for them (bigger in size, bigger in revenue, more jobs created?), SMEs and entrepreneurship will then contribute to strengthen the Brazilian economy. BNDES, however, shows development as a direct result of lending money to all size companies. Development for the United Nation Development Program is, among other things, taking people out of poverty and encouraging "the protection of human rights and the empowerment of women, minorities and the poorest and most vulnerable" (Undp, 2017). That is not clear in the way the bank communicates to their public. Mazzucato (2013) says that Brazilian state has been driving innovation in the country and BNDES is one of the main actors in this effort. She states that BNDES is picking national champions and focusing on them - and that's what BNDES president refutes on headline \#5 (see Fig. 3). In this way, the state would be creating new technological opportunities, making large initial investments and developing risky research that would later benefit private agents. This benefit, however, can create a parasitic, rather than a symbiotic relationship, when the private sector doesn't return the benefits it has received to the state. If Mazzucato (2013) is right, BNDES is inserted in the capitalist flow as proposed by Schumpeter $(2008 ; 1975)$ in his early and later work - focusing on innovative start-ups and financing innovation in big companies. For him, this is how entrepreneurship causes disturbances in the economic flow and contributes to economic development. For Mazzucato (2013), this unequal distribution of the benefits of innovation would be a factor for increasing social inequality, instead of reducing 
it. In that way, BNDES would be serving "conservative political or economic (capitalist) ends" (Tedmanson et al., 2012, p. 536), reproducing conservative assumptions.

Both websites are not welcoming to micro and small entrepreneurs. The revenue figures in the BNDES and the information aimed at the MEI just at the bottom of the page on Sebrae's website don't clearly states that both agencies are the places where they can find help. BNDES website also fails in presenting to the entrepreneur how to get access to credit. It links to its partners institutions, but doesn't give enough information on what to do. Although both agencies namely should be working to help micro, small and medium entrepreneurs, not being welcoming to these publics may mean that they are just reproducing privileged positions of some groups or business elites in the access of guidance and financing.

A recent study made by Fundação Getulio Vargas for Sebrae/RJ shows that in the largest communities in the city of Rio de Janeiro, guidance offered by Sebrae has a significant impact on the compliance rates of MEI. The research conducted with 20,191 entrepreneurs serviced by Sebrae indicates that those receiving guidance sessions were paying their taxes on time 15\% more often than those not receiving training (Fgv, 2017). When we see the figures for entrepreneurs searching for support at only 14.1\% (Empreendedorismo no Brasil: 2015, 2016), it seems to be a problem. Although we don't see any clear statement claiming that business owner supported by both agencies need to be innovative, there is no emphasis on treating have-nots, barefoot, or micro [informal] entrepreneurs as their public. Information about the services designed for them are not clear. Perhaps the agencies would need a plural discourse that any entrepreneur, from anywhere, could understand. By now, it seems to be talking, at most, to the category of involuntary entrepreneurs Filion (1999) presents.

As we have seen, Imas et al. (2012) say that peripheral publics would need to play a more central role in organizing and managing these initiatives aimed at them, in order to work. The same propositions made by Hall et al. (2012): people in the base of the pyramid need involvement in policies designed for them, to reduce social exclusion.

When we analyze the ten most relevant news according to Google from 2017 for BNDES, what we note is that the majority of them is about providing funds for start-up companies. Two out of ten headlines are saying that BNDES is announcing funds for innovative companies, one for start-ups and the other one for incubators and tech parks. One of the headlines is saying that BNDES is targeting R $\$ 8.2$ billion in credit for small and micro enterprises, but the most relevant headline on the search, however, says that the volume of credit distributed to SMEs has decreased, due to augmented risk in transactions. The other news are more focused on the politics of the bank, rather than in credit policy for SMEs.

Analyzing the ten most relevant news from 2017 for Sebrae we note that the majority of them is about events and data on entrepreneurship. Only one is about training for small entrepreneurs and two about opportunities to start new businesses. One of the headlines is the same about aiming R $\$ 8.2$ million in credit for small and micro enterprise and one is about the effort to reduced red-tape and facilitate opening news businesses. News about Sebrae are less focused on innovative entrepreneurs. On the other hand, they are also not clearly stating who is the public for the agency. Although news about Sebrae are somewhat vague, BNDES is not only aiming to support gazelle companies and start-ups, but is clearly protecting the societal logic that keeps people that already have more access to resources in the top of priorities, whether that is intentional or not. BNDES even tries to avoid the accusation of picking winners, but the bank actually seems to be doing so when most of what one hears is about tech companies and start-ups. 


\section{Conclusion}

While the majority of the work in the field of entrepreneurship is located in the functionalist paradigm (Perren \& Jennings, 2005), this work seeks to bring light to it from an interpretative point of view, critically discussing how discourse influences the provision of services to entrepreneurs. In doing so, the objective of this CDA was to analyze how and if barefoot entrepreneurs and micro, small and medium entrepreneurs fit in the discourse proclaimed by Sebrae and BNDES and are not just reproducing the high-growth / innovative discourse that would exclude the majority of Brazilians self-employed or running lifestyle businesses. This is the first academic contribution. In an indirect way, this paper also contributes to the discussion about the unquestioned path entrepreneurship policies have become a "magic bullet" (Shane, 2009) and how the Schumpeterian view has become the most influential (Ogbor, 2000).

This work is also normative (Fairclough, 2010). Job market crisis and many years of recession have thrown millions on self-employment or running micro or SMEs. Understanding failures in the communication between agencies that provide services to citizens and its beneficiaries is the major managerial contribution of this work, aiming to make them more permeable to people outside the Schumpeterian discourse or, in other words, have-nots willing to start a business, the self-employed and micro, small and medium entrepreneurs. Policies should not exclude, but protect these people. In order to do so, Sebrae and BNDES should be more user friendly in language and websites, helping their publics to understand that these agencies are also designed for them. Press release and tutorials, distance learning, easy to access channels, among other solutions, could be used specially by BNDES to educate their possible beneficiaries. Brazil has a tradition of more than 40 years of community banks and BNDES provides funds for some of them since 1996 (Monzoni Neto, 2006). Increasing the relationship with community banks and helping them to go online would facilitate access to microcredit. For Sebrae, a discourse saying that even people without CNPJ can get aided and how to do that, showing a clear path would help to avoid socio-economical cleavage and keeping thousands of people from receiving training and advice.

A limitation of this article is the fact that it has only analyzed both Sebrae and BNDES websites and the ten most relevant news on Google for the year of 2017. It didn't go further in documents and didn't visit any Sebrae office. For future studies, in order to support a deeper critical discourse analysis and broaden the understanding about the agencies, more documents should be screened and in-dept interviews with both the beneficiaries and managers of these agencies could be used. Future research could also perform quantitative analysis following up on what has been suggested here, checking the number of individuals that did try to use the services of BNDES and Sebrae but didn't go further because the information available was not welcoming or seen the agencies as not suitable for them.

\section{References}

Acs, Z. J., Åstebro, T., Audretsch, D. B., \& Robinson, D. T. (2016). Public policy to promote entrepreneurship: A call to arms. Small Business Economics, 47(1), 35-51.

Andreassi, T., Flory, H., \& Teixeira, M. A. C. (2013). Políticas públicas de empreendedorismo para a população de baixa renda: transformando necessidades em oportunidades. Cadernos Gestão Pública e Cidadania, v. 19, 1-25. 
Åstebro, T. (2017). The private financial gains to entrepreneurship: Is it a good use of public money to encourage individuals to become entrepreneurs?. Small Business Economics, 48 (2), 323-329.

Bndes, 2017a. Banco Nacional de Desenvolvimento Econômico e Social (Accessed June 2017). https://www. bndes.gov.br.

Bndes, 2017b. Banco Nacional de Desenvolvimento Econômico e Social. Quem Somos. (Accessed March 2017). https://www.bndes.gov.br/wps/portal/site/home/quem-somos.

Bndes, 2018. Banco Nacional de Desenvolvimento Econômico e Social (Accessed August 2018). https:// www.bndes.gov.br.

Borges Junior, C., Andreassi, T., \& Nassif, V. (2017). (A Falta de) Indicadores de empreendedorismo no Brasil. REGEPE - Revista de Empreendedorismo e Gestão de Pequenas Empresas, 6(3), 1-9.

Burrell, G.,\& Morgan, G. (1979). Sociological paradigms and organisational analysis: elements of the sociology of corporate life. Heinemann Educational Books, London.

Chiles, T. H., Bluedorn, A. C., \& Gupta, V. K. (2007). Beyond creative destruction and entrepreneurial discovery: a radical Austrian approach to entrepreneurship. Organization Studies, (4), 467-493.

de Almeida, F., Valadares, J., \& Sediyama, G. (2017). A contribuição do empreendedorismo para o crescimento econômico dos estados brasileiros. REGEPE - Revista de Empreendedorismo e Gestão de Pequenas Empresas, 6(3), 466-494.

Drucker, P.F. (1985). Innovation and entrepreneurship: practice and principles. Harper \& Row, New York.

Empreendedorismo no Brasil: 2015. (2016) Relatório executivo: GEM - Global Entrepreneurship Monitor. IBQP-PR, Curitiba.

Época Negócios, 2017. Bancos travam crédito do BNDES a pequenas empresas. (Accessed May 2018). https://epocanegocios.globo.com/Empreendedorismo/noticia/2017/07/epoca-negocios-bancos-travam-credito-do-bndes-a-pequena-empresa.html.

Fairclough, N. (2001). Discurso e mudança social. UnB, Brasília.

Fairclough, N. (2010). Critical discourse analysis: the critical study of language. Longman, . London; New York.

Fgv, 2017. Fundaçãp Getulio Vargas. Estudo avalia impacto do atendimento do Sebrae na adimplência do 
MEI em comunidades (Accessed June 2017). http://portal.fgv.br/noticias/estudo-avalia-impacto-atendimento-sebrae-adimplencia-mei-comunidades.

Filion, L. J. (1999). Empreendedorismo: empreendedores e proprietários-gerentes de pequenos negócios. Revista de Administração, 34(2), 6-28.

Furlong, P; \& Marsh, D. (2010). A skin not a sweater: ontology and epistemology in political science. In Marsh, D., \& Stoker, G. (2010). Theory and methods in political science. Basingstoke: Palgrave Macmillan. 184-211.

Gomes, M. P., Alves, M. A., \& Fernandes, R. R. (2013). Políticas públicas de fomento ao empreendedorismo e às micro e pequenas empresas. Programa Gestão Pública e Cidadania, São Paulo.

Hall, J., Matos, S., Sheehan, L., \& Silvestre, B. (2012). Entrepreneurship and Innovation at the Base of the Pyramid: A Recipe for Inclusive Growth or Social Exclusion? Journal of Management Studies, 49: 785-812.

Hall, J.C., \& Sobel, R.S., (2006). Public Policy and Entrepreneurship. The Center for Applied Economics. The University of Kansas. Technical Report 06-0717.

Henderson, J. (2002). Building the rural economy with high-growth entrepreneurs. Federal Reserve Bank of Kansas City Economic Review 87 (3): 45-70.

Henrekson, M., \& Stenkula, M. (2010). Entrepreneurship and public policy. In Acs Z. J., \& Audretsch, D. B. (Eds.) (2010). Handbook of entrepreneurship research. International handbook series on entrepreneurship. Berlin: Springer. 595-637.

Independent (2018). Silicon Valley giant's popular service uses complex algorithm to assess page quality (Accessed September 2018). https://www.independent.co.uk/life-style/gadgets-and-tech/news/google-news-headlines-stories-ranking-algorithm-editors-publishers-journalism-a8404811.html.

Iñiguez, L., \& Antaki, C. (1994). El análisis del discurso en Psicología Social. Boletín de Psicología, 44, 5775 .

Imas, J.M., Wilson, N. \& Weston, A. (2012). Barefoot entrepreneurs. Organization, 19, 5, 563-585.

Macedo, M. M., et al. (2016). Global Entrepreneurship Monitor - Empreendedorismo no Brasil : 2015 Coordenação de Simara Maria de Souza Silveira Greco. IBQP, Curitiba.

Mautner, G. (2005). Time to get wired: Using web-based corpora in critical discourse analysis. Discourse \& Society, 16(6), 809-828. 
Mazzucato, M. (2013) The entrepreneurial state: debunking public vs. private sector myths. Anthem Press, London.

Minniti, M. (1999). Entrepreneurial activity and economic growth. Global Business and Economics Review $1(1): 31-42$.

Minniti, M. (2008), The role of government policy on entrepreneurial activity: productive, unproductive, or destructive?. Entrepreneurship Theory and Practice, 32: 779-790.

Monzoni Neto, M. P. (2006). Impacto em renda do microcrédito: uma investigaçào empírica sobre geraçâo de renda do Crédito Popular Solidario (Saão Paulo Confia), no Municipio de São Paulo. PhD dissertation. EAESP-FGV, São Paulo.

Nyström, K. (2008). Is entrepreneurship the salvation for enhanced economic growth? CESIS Working Paper Series No. 143, CESIS, Royal Institute of Technology, Stockholm.

Ogbor, J. O. (2000), Mythicizing and reification in entrepreneurial discourse: Ideology $\square$ critique of entrepreneurial studies. Journal of Management Studies, 37: 605-635.

Portal do Empreendedor - MEI (2018). (Accessed June 2018). http://www.portaldoempreendedor.gov.br/estatisticas.

Perren, L., \& Jennings, P. L. (2005). Government discourses on entrepreneurship: issues of legitimization, subjugation, and power. Entrepreneurship Theory and Practice, 29: 173-184.

Santos, F. d. (2013). A atuação dos governos locais na redução das desigualdades socioeconômicas. PhD dissertation. EAESP-FGV, São Paulo.

Schumpeter, J. A. (1975). Capitalism, socialism and democracy. Haper Torchbooks, New York.

Schumpeter, J. A. (2008). The theory of economic development: an inquiry into profits, capital, credit, interest, and the business cycle. Transaction, New Brunswick.

Sebrae, 2017. Serviço Brasileiro de Apoio às Micro e Pequenas Empresas (Accessed June 2017). http://www. sebrae.com.br/sites/PortalSebrae.

Sebrae, 2018. Serviço Brasileiro de Apoio às Micro e Pequenas Empresas. Quem Somos (Accessed August 2018). http://www.sebrae.com.br/sites/PortalSebrae/canais_adicionais/conheca_quemsomos.

Shane, S. (2009). Why encouraging more people to become entrepreneurs is bad public policy. Small Business Economics, 33(2), 141-149. 
Tedmanson, D., Verduyn, K., Essers, C., \& Gartner, W.B. (2012). Critical perspectives in entrepreneurship research. Organization, 19(5): 531-541.

Timmons, J. A., \& Spinelli S. (2004). New venture creation: entrepreneurship for the 21 st century. McGrawHill/Irwin, Boston.

Undp, 2017. United Nations Development Program. About us (Accessed May 2017). http://www.undp.org/ content/undp/en/home/operations/about_us.html.

University of Leicester. (2015). 20 Critical Entrepreneurship Studies (Accessed March 2018). http://www2. le.ac.uk/conference/previous/cms15/sub-streams/20-critical-entrepreneurship-studies.

van Dijk, T. A. (2001). Critical discourse analysis. In Tannen, D., Schiffrin, D., \& H. Hamilton, H. (Eds.), Handbook of discourse analysis. Oxford: Blackwell. 352-371.

Zacharakis, A. L., Bygrave, W. D. \& Shepherd, D. A. (2000) Global Entrepreneurship Monitor: National Entrepreneurship Assessment: United. States of America. Kauffman Center for Entrepreneurial Leadership, Kansas City. 